\title{
FORMA URBANA DE BELÉM E SEUS DESDOBRAMENTOS PARA A FORMAÇÃO DE UM SISTEMA DE ESPAÇOS LIVRES ACESSÍVEL À POPULAÇÃO
}

\author{
BELÉM'S BUILT FORM AND ITS DEVELOPMENTS TO THE FORMATION OF A SYSTEM OF \\ OPEN SPACES ACCESSIBLE TO POPULATION
}

\author{
Ana Claudia Duarte Cardoso* \\ José Julio Ferreira Lima** \\ Raul Ventura Neto*** \\ Roberta Menezes Rodrigues**** \\ Juliano Pamplona Ximenes***** \\ Taynara do Vale Gomes ${ }^{* * * * * *}$
}
Arquiteta urbanista pela Faculdade de Arquitetura e Urbanismo da Universidade Federal do Pará (FAU-UFPA). Mestre em Planejamento Urbano pela Universidade de Brasília (UnB). PhD em Ar- quitetura pela Oxford Brookes University. Professora associada do Programa de Pós-Graduação em Arquitetura e Urbanismo na Faculdade de Arquitetura e Urbanismo da Universidade Federal do Pará (FAU/PPGAU/UFPA). Laboratório Cidades na Amazônia, Instituto de Tecnologia. Avenida Augusto Corrêa, 01, 66075-110, Cidade Universitária, Setor Profissional, Belém, PA, Brasil. aclaudiacardoso@gmail.com
** Arquiteto urbanista pela Faculdade de Arquitetura e Urbanismo da Universidade Federal do Pará (FAU-UFPA). Mestre em Desenho Urbano pela Oxford Brookes University e PhD em Arquitetura pela mesma universidade. Professor do Programa de Pós-Graduação em Arquitetura e Urbanismo na FAU-UFPA. Laboratório Cidades na Amazônia, Instituto de Tecnologia. Avenida Augusto Corrêa, 01,66075-110, Cidade Universitária, Setor Profissional, Belém, PA, Brasil.
ijlimaufpa@gmail.com
*** Arquiteto e urbanista, mestre em Arquitetura e Urbanismo pela Faculdade de Arquitetura e Urba- nismo da Universidade Federal do Pará (FAU-UFPA). Doutorando em Desenvolvimento Econô- mico pelo Instituto de Economia da Universidade Estadual de Campinas (Unicamp). Laboratório Cidades na Amazônia, Instituto de Tecnologia. Avenida Augusto Corrêa, 01, 66075-110, Cidade Universitária, Setor Profissional, Belém, PA, Brasil.
netoventuraraul@gmail.com
**** Arquiteta e urbanista pela Faculdade de Arquitetura e Urbanismo da Universidade Federal do Pará (FAU-UFPA). Mestre em Planejamento do Desenvolvimento pela UFPA - Núcleo de Altos Estudos Amazônicos (NAEA). Doutora em Integração da América Latina pelo Programa de Pós- - Graduação em Integração da América Latina da Universidade de São Paulo (PROLAM/FAUUSP). Professora na FAU-UFPA. Laboratório Cidades na Amazônia, Instituto de Tecnologia. Avenida Augusto Corrêa, 01, 66075-110, Cidade Universitária, Setor Profissional, Belém, PA, Brasil. roberta.menezes@uol.com.br
***** Arquiteto e urbanista pelo Faculdade de Arquitetura e Urbanismo da Universidade Federal do Pará (FAU-UFPA). Doutor em Planejamento Urbano e Regional pelo Instituto de Pesquisa e Planeja- mento Urbano da Universidade Federal do Rio de Janeiro (IPPUR-UFRJ). Professor na Faculdade de Arquitetura e Urbanismo da UFPA. Laboratório Cidades na Amazônia, Instituto de Tecnologia. Avenida Augusto Corrêa, 01, 66075-110, Cidade Universitária, Setor Profissional, Belém, PA, Brasil. julianoximenes@gmail.com
****** Arquiteta e urbanista pela Faculdade de Arquitetura e Urbanismo da Universidade Federal do Pará (FAU-UFPA). Mestranda em Arquitetura e Urbanismo no Programa de Pós-Graduação em Arquitetura e Urbanismo da UFPA. Laboratório Cidades na Amazônia, Instituto de Tecnologia. Avenida Augusto Corrêa, 01, 66075-110, Cidade Universitária, Setor Profissional, Belém, PA, Brasil. taynaragomes@gmail.com


Ana Claudia Duarte Cardoso, José Julio Ferreira Lima, Raul Ventura Neto,

Roberta Menezes Rodrigues, Juliano Pamplona Ximenes, Taynara do Vale Gomes

\section{RESUMO}

Este texto apresenta uma caracterização do espaço construído de Belém, destacando sua condição estuarina, fisiografia e evolução socioespacial, mas iluminando elementos de desarticulação nas estratégias de operação dos agentes envolvidos na produção da cidade e da gestão urbanística para a estruturação de um Sistema de Espaços Livres e a forma limitada como os mesmos são apropriados pela população. $O$ artigo baseia-se nas conclusões da Oficina Quapá SEL realizada em Belém em maio de 2015, na qual professores e estudantes da Universidade Federal do Pará e a equipe de professores e bolsistas da Universidade de São Paulo realizaram a avaliação dos espaços públicos da cidade. Observou-se que há notável diferenciação da paisagem da área central em oposição/contraposição à área de expansão da cidade e comprometimento de Áreas de Preservação Permanente (APPs) nas margens dos rios internos e das ilhas, principais espaços verdes do município e elementos de conexão com o bioma amazônico que, embora possua potencial paisagístico, vem sendo apropriado de forma socialmente desigual.

Palavras-chave: Belém. Espaços livres. Produção do espaço construído. Gestão urbanística.

\section{ABSTRACT}

This paper presents a characterization of the built space of Belém highlighting, its estuarine condition, physical geography and its economic, social and spacial development. It is based on Quapá-SEL Workshop conclusions held in Belém, in May 2015, in which teachers and students from São Paulo and Pará Federal Universities assessed the conditions of urban open spaces of the city. The results highlight a disarticulation between real estate agents strategies and of urban management towards structuring an Open Spaces System (SEL in Portuguese), as well as its limited appropriation by the population. There is a remarkable differentiation between the landscapes of central area in opposition / contraposition to that at the city's expansion area. This debate showed how much permanent preservation areas on the banks of inland rivers and islands (the main green spaces of the city and main linkage with the Amazonian biome), with its landscape potentials, have been unevenly appropriated in the city, through gentrification.

Keywords: Belém. Open spaces. Built space production. Urban management.

\section{BELÉM: CARACTERIZAÇÃO DO SISTEMA DE ESPAÇOS LIVRES}

A cidade de Belém é polo de uma região metropolitana que articula características regionais e atributos típicos das metrópoles brasileiras. A paisagem regional pode ser vista em elementos naturais específicos, devido à sua localização em uma das mais extensas regiões estuarinas do planeta, sob influência de grandes rios que circundam a cidade, mas também de inúmeras bacias de rios internos com forte influência sobre o sítio (composto por terras firmes e "baixadas" ou várzeas alagáveis) e sobre as formações de vegetação (tropical, de grande porte e de ocorrência em grandes massas) observadas em 2016, na sua forma original, nas cerca de quarenta ilhas que compõem a porção rural do município.

As peculiaridades desse sítio geraram uma estratégia de ocupação espacial que segue a margem do rio, em que pese a dependência histórica entre o modal fluvial e as atividades mercantis associadas às práticas extrativistas que caracterizavam os ciclos econômicos durante o período de isolamento da região. Mesmo já existindo, desde a década de 1930, algum tipo de articulação mercantil com o mercado interno, foi somente a partir do final da década de 1960 que a integração espacial e econômica da região ao mercado nacional se aprofundou, agudizando desigual- 
dades socioeconômicas e produzindo transformações na rede urbana e no espaço intraurbano da região.

É desse marco em diante que a antiga cidade primaz (CORRÊA, 1987) foi transformada em região metropolitana' e assumiu processos de ocupação e expansão associados a eixos rodoviários, e não mais às margens dos rios, onde o protagonismo da ação dos agentes produtores do espaço urbano capitalista dificulta a articulação de processos fundiários e condições de legislação urbanística. Notavelmente, aprofundou-se uma lógica fundiária moderna, capitalista - nos moldes latino-americanos -, em que a propriedade privada do solo urbano convive com índices altos de precariedade da moradia e a administração pública se revela mais associada às elites econômicas regionais do que a qualquer modalidade de interesse público.

O processo de formação da porção continental de Belém, como em qualquer cidade, apresenta alguns condicionantes do sítio físico. No caso da cidade, etapas sucessivas de ocupação de cotas mais altas do solo foram seguidas por drenagem das áreas alagadas existentes nos interstícios entre as áreas inicialmente ocupadas. Assim foram articulados os bairros da Cidade Velha e Campina, no início do século XIX, através do aterro do Piri (CRUZ, 1973), ou os bairros do Reduto e Umarizal, após o aterro do igarapé das Almas, nos anos 1960.

As áreas de baixada eram tidas como obstáculos à urbanização e limitaram a implantação do plano de alinhamento do início do século XX, que orientou a ocupação da Primeira Légua Patrimonial da cidade às áreas altas. A ocupação da referida Légua só foi concluída nos anos 1960, quando já iniciados o processo de ocupação informal das baixadas, a verticalização das áreas mais nobres da cidade e a substituição dos fartos quintais por vilas nas áreas consolidadas. Esse plano de alinhamento demonstra evidente tendência do urbanismo racionalista em ignorar aspectos do sítio físico e, ao mesmo tempo, a insalubridade da moradia - o que a partir dos anos 1960 passava a ser chamado de "vazio urbano". (MARICATO, 2001). Um cinturão verde foi formado, desde os anos 1940, limitando a Primeira Légua, estabelecido a partir de usos institucionais diversos - áreas militares, Universidade Federal do Pará (UFPA), Empresa Brasileira de Pesquisa Agropecuária (Embrapa), aeroportos, mananciais - que têm sido preservados até o presente, mas que já começam a sofrer ameaça de desaparecimento face à grande valorização da terra e à agressividade dos agentes imobiliários (mapa 1)².

Lei Complementar $n^{\circ}$ 14, de 8 de junho de 1973. Estabelece as regiões metropolitanas de São Paulo, Belo Horizonte, Porto Alegre, Recife, Salvador, Curitiba, Belém e Fortaleza. Brasília: Presidência da República, 1973. Diário Oficial, 11 jun. 1973, p. 5.585. Disponível em: <http://www.planalto.gov.br/ccivil_03/leis/lcp/Lcp14. htm >. Acesso em: 11 jun. 2015.

2 O território do município de Belém formou-se, inicialmente, por meio da destinação de terras pela Coroa Portuguesa em 1627, com a doação de uma légua de terra (cerca de 6.600 metros em linha reta do núcleo de origem da cidade) mediante Carta de Doação de Sesmarias em favor do antigo conselho da Câmara. A chamada "Primeira Légua Patrimonial" de Belém corresponde, atualmente, à porção mais central e de ocupação mais antiga do município, onde anteriormente vigia o regime enfitêutico de gestão de tal patrimônio. Em 1899, foi doada pelo governo do estado uma "Segunda Légua Patrimonial", que nunca foi definitivamente demarcada, correspondendo à atual área de expansão de Belém, a principal frente de valorização imobiliária do município. (PREFEITURA MUNICIPAL DE BELÉM - PMB, 2000). 
Ana Claudia Duarte Cardoso, José Julio Ferreira Lima, Raul Ventura Neto,

Roberta Menezes Rodrigues, Juliano Pamplona Ximenes, Taynara do Vale Gomes

A Primeira Légua corresponde ao atual centro metropolitano e conta com uma quadrícula como sistema de ruas em áreas altas, em termos relativos para o sítio de Belém (em média entre 12 e 28 metros), e com prolongamentos dessas ruas em uma estrutura deformada nas áreas de baixada. A prática dos aterros de quintais, e até de leitos de igarapés, foi um dos fatores que levou ao desaparecimento ou tamponamento dos rios internos para a população, enquanto as práticas econômicas assumiram as margens dos grandes rios que limitam a cidade. A partir da década de 1990, essas margens tornaram-se lugares preferenciais para a instalação de equipamentos públicos e espaços livres, com adaptação de instalações portuárias (Estação das Docas), reforma e restauração de áreas históricas (Feira do Ver-o-Peso, Conjunto Feliz Lusitânia) e tratamento de áreas públicas (Espaço Ver-o-Rio, parque Mangal das Garças, aterro do Portal da Amazônia), somando novas tipologias de espaços livres a praças e parques herdados na época da Borracha (figura 1).

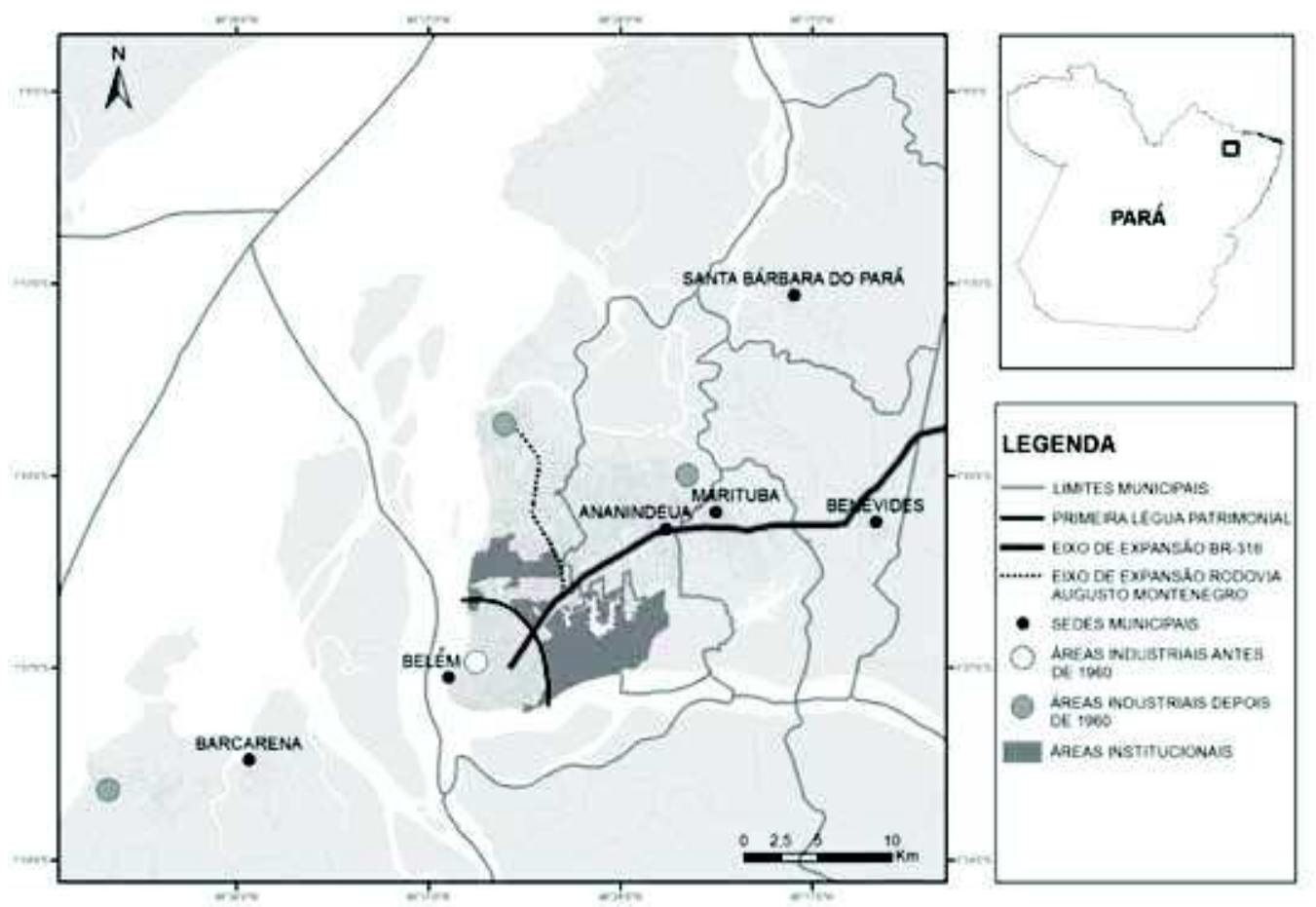

Mapa 1 Belém e sua Região Metropolitana - Marcação da Primeira Légua Patrimonial e dos Eixos de Expansão. Fontes: Instituto Brasileiro de Geografia e Estatística (IBGE), 2010, e Companhia de Desenvolvimento e Administração da Área Metropolitana de Belém (CODEM), 2003.

Em termos de periodização das formas de tratamento técnico ou apropriação da água na região, pode-se associar às intervenções sob o padrão do Plano Nacional de Saneamento (Planasa) a parte significativa da impermeabilização de taludes de cursos d'água urbanos em Belém e municípios do entorno, com evidentes impactos sobre o padrão de drenagem dos municípios metropolitanos - o já célebre fenômeno de aceleração do pico de cheia a jusante, inevitável nesse tipo de concepção. (BUENO, 


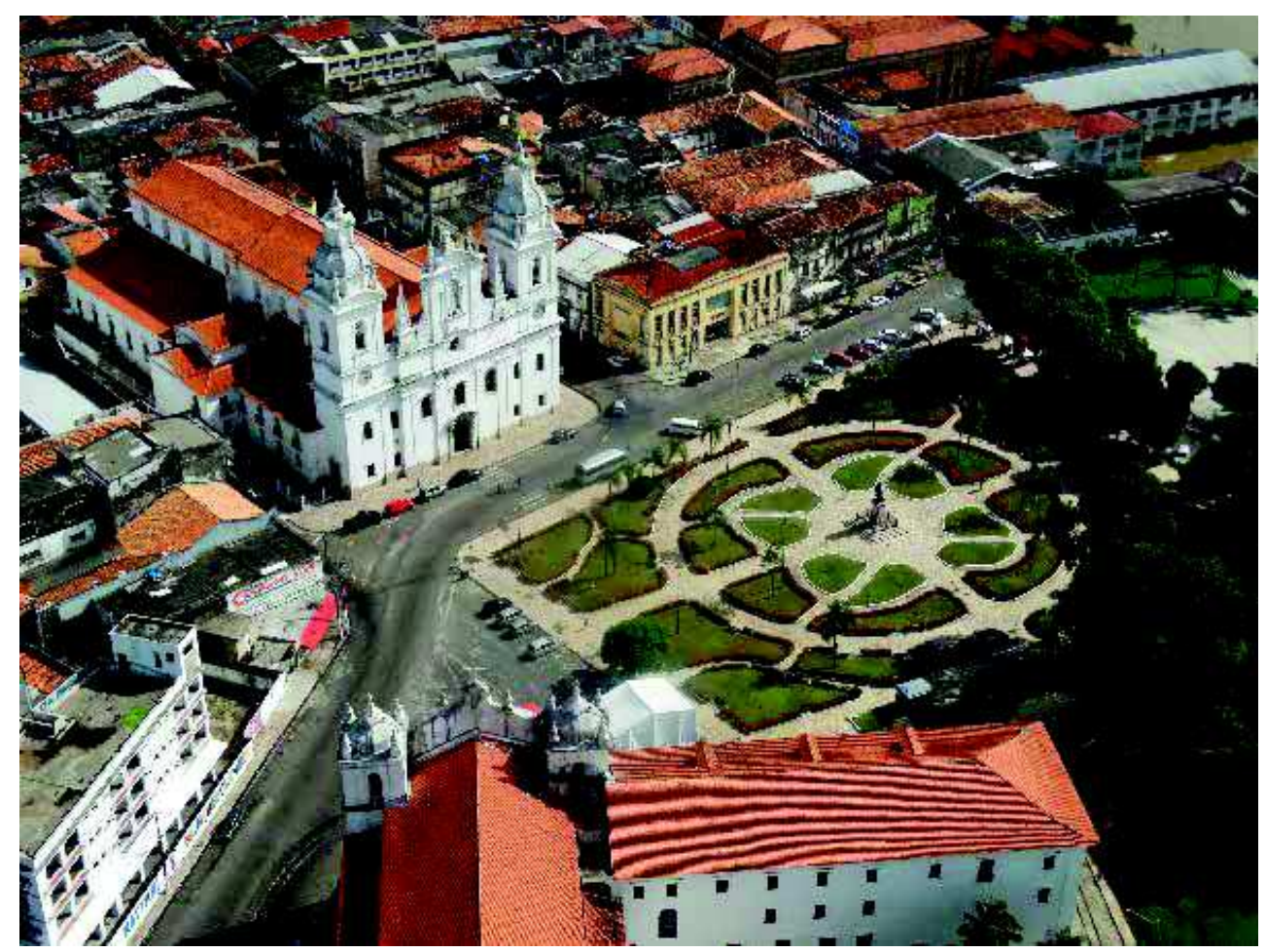

Figura 1 Conjunto Feliz Lusitânia.

Foto: Silvio Soares Macedo, 2014.

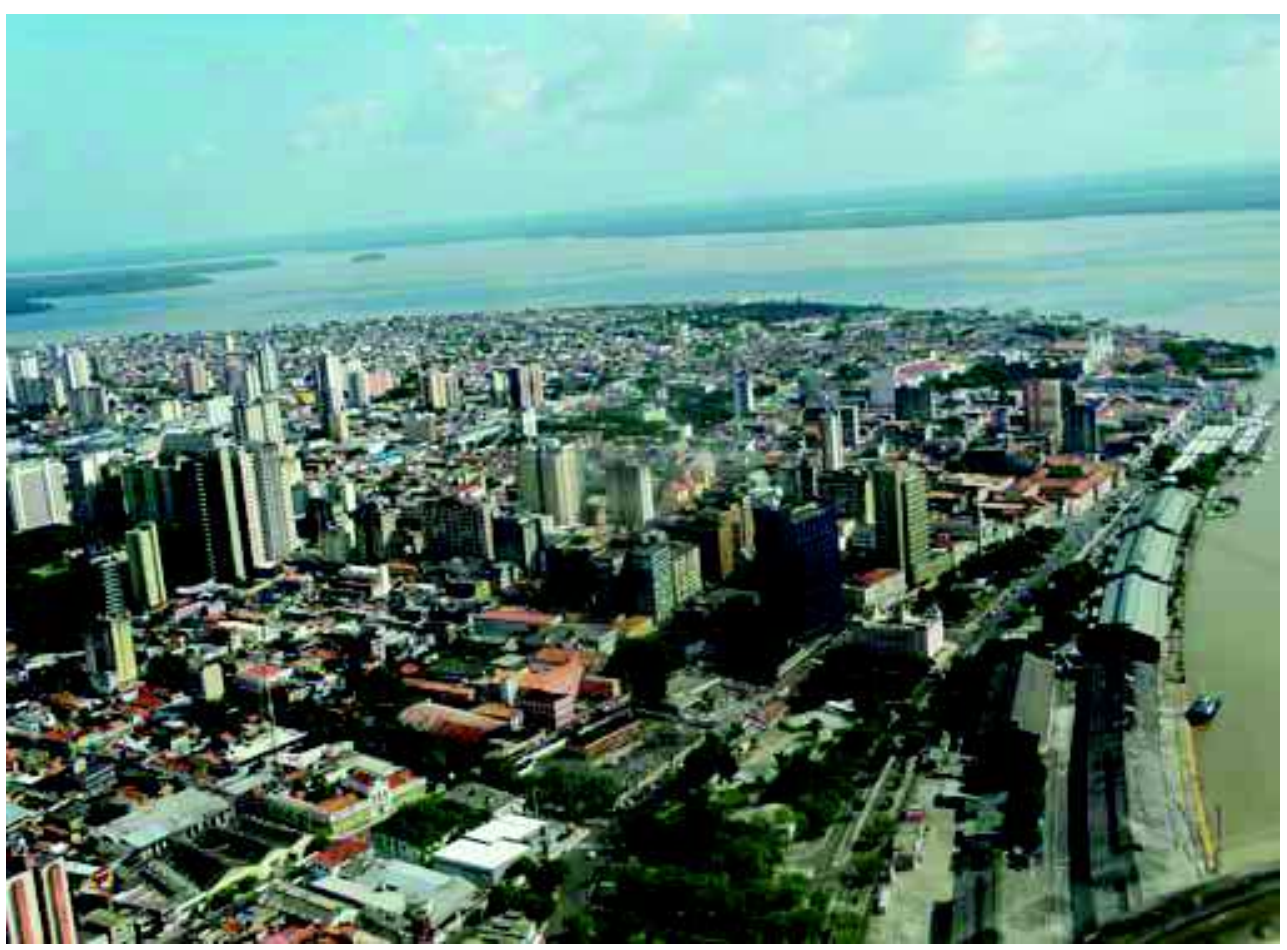

Figura 2 Avenidas Marechal Hermes e Boulevard Castilhos França, áreas de aterro que viabilizaram áreas verdes e galpões do porto de Belém na virada do século XX. Estação das Docas e feira do Ver-oPeso ao fundo.

Foto: Silvio Soares Macedo, 2014. 
Ana Claudia Duarte Cardoso, José Julio Ferreira Lima, Raul Ventura Neto,

Roberta Menezes Rodrigues, Juliano Pamplona Ximenes, Taynara do Vale Gomes

2006). Esse problema, quando visto historicamente, em paralelo com a crescente favelização das cidades metropolitanas a partir da ditadura entre os anos de 1964-1985, demonstra uma paisagem em que as águas ora são objeto de retificação e acentuação do risco e do impacto do alagamento, ora são contaminadas devido à ausência de tratamento de esgotos e aos efeitos urbanísticos da moradia precária.

A diferenciação dessa área da cidade quanto a condições de mobilidade, de acesso a espaços públicos (ruas e praças) e maior grau de provisão de infraestrutura e condições físicas (dimensões de ruas, quadras e lotes) na sua porção formal - e de acessibilidade das baixadas - em que pesem a precariedade física e o processo gradual de consolidação e inserção à cidade - garantiu por décadas a avaliação de melhor qualidade da experiência urbana e motivou grande disputa pela exploração de seu solo, particularmente das áreas altas e ocupadas formalmente, pelo setor imobiliário. A partir de 2005, áreas que foram ocupadas informalmente na margem do rio Guamá estão sofrendo intervenções (aterros) para gerar solo e viabilizar novos empreendimentos de interesse do setor imobiliário e do setor de comércio e serviços (como é o caso do aterro do Portal da Amazônia, no bairro do Jurunas.

A ação do governo federal na macrodrenagem do igarapé das Almas e na produção de habitação popular, a partir da década de 1970, associou ações de remanejamento e produção de conjuntos habitacionais financiados pelo Banco Nacional de Habitação (BNH) para além do cinturão institucional, com a ocupação da Segunda Légua Patrimonial, área de expansão da cidade. (LIMA; VENTURA NETO; LOPES, 2015; TRINDADE JR., 1998). A ocupação imobiliária desse vetor de expansão interno à Segunda Légua de Belém é, por sua vez, orientada por um dos ramais da antiga ferrovia que conectava a capital ao nordeste do estado, posteriormente denominado rodovia Augusto Montenegro, quando do encerramento da ferrovia e da pavimentação do antigo ramal.

A definição fundiária das terras na época da abertura do ramal ferroviário, provavelmente para uso em atividades agrícolas, condicionou a ocupação urbana de boa parte da área de expansão e a consequente formação do sistema viário, resultando numa estrutura de "espinha de peixe", que tem a avenida Augusto Montenegro como principal eixo de acesso a diversas tipologias/morfologias que emergiram nessa porção da cidade.

Nessa área constituem-se processos de fragmentação e segregação diferentes dos observados na Primeira Légua, onde a ação do poder público e do setor privado na produção de conjuntos habitacionais alternou-se por décadas durante a produção de loteamentos informais e as ocupações nos vazios deixados nos interstícios dos primeiros. A partir da década de 1990, as maiores glebas de terra, lindeiras à avenida Augusto Montenegro, foram ocupadas por condomínios fechados de alto padrão, murados e arborizados por vegetação exógena. A partir da década de 2010, esses empreendimentos passaram a articular condomínios verticais e torres comerciais a shopping centers, constituindo novas subcentralidades - que esperam (ou, num discurso publicitário, afirmam produzir...) rivalizar com as condições de moradia estabelecidas na Primeira Légua Patrimonial. 
Forma Urbana de Belém e seus Desdobramentos para a Formação de um Sistema de Espaços Livres Acessível à População

Grande transformação de uso ocorreu ao longo da avenida, sem haver mudança nos espaços públicos ou atenção à consolidação de um sistema de ruas e espaços livres compatível com a demanda por áreas públicas, ou sequer suficiente para atender as necessidades de mobilidade da população, cada vez mais dependente de modais individuais, em face da carência de sistema de transporte público. Nessa parte da cidade, quando existem espaços públicos equipados com mobiliário adequado para as diversas atividades humanas, estes são contidos em empreendimentos privados. A forma urbana que parece decorrer desse novo padrão de expansão, em torno da rodovia Augusto Montenegro, apresenta condomínios residenciais, verticais ou horizontais, com densidade moderada e empreendimentos em terrenos de porte relativo, sempre atendidos por desenhos viários favoráveis a automóveis de passeio e seu estacionamento. A alternância entre aglomerados de torres residenciais, casas, shopping centers, supermercados, postos de gasolina, lojas de material de construção e demais tipos de comércio, serviços e órgãos públicos, mostra paisagens urbanisticamente empobrecidas, com sintaxe simplória e alguma vulgaridade morfológica, própria de periferias urbanas em reconfiguração nos termos estritos do mercado imobiliário. O citado traçado "espinha-de-peixe", não projetado, sinaliza deficiências objetivas de integração espacial no plano local (LIMA, 2001), isolando e segregando as numerosas ocupações precárias situadas por acessos indiretos, posteriores à rodovia e à ocupação formal, com crescente perfil de classe média no eixo da via.

\section{ELEMENTOS DA DESARTICULAÇÃO DO SISTEMA DE ESPAÇOS LIVRES: MORFOLOGIA, AGENTES E LEGISLAÇÃO}

A inserção de Belém em uma formação econômica periférica auxilia, em parte, a compreensão de sua urbanização precária, marcada pelo atendimento deficiente de direitos sociais e acesso à infraestrutura. Nesse sentido, são mais impactantes sobre seu espaço urbano os períodos de estagnação entre ciclos econômicos, até o ponto de reativação das fases de crescimento, que se aproveitam de possibilidades renovadas de concentração da renda produzidas pelos setores da economia urbana local que possuem alguma base imobiliária. (LIMA; VENTURA NETO, 2015). Em face dessa condição, espaços livres e edificados da cidade têm incorporado à sua gênese reprodutiva, de um modo ou de outro, os resultados dessa dinâmica cíclica, própria da formação econômica brasileira.

O estado, particularmente, o poder local - que a princípio poderia servir como mediador desse conflito - tem atuado de forma associada às coalizões urbanas locais, interessadas em transformar a cidade numa Máquina de Crescimento: "[...] organização de tipo empresarial voltada a aumentar o volume de renda agregada por meio da intensificação da utilização da terra [...]". (FIX, 2007, p. 24). Especificamente em Belém, nota-se que a forma como a regulação urbanística é realizada apresenta, de certo modo, indicativos desse comprometimento, definindo o desenho de macroparcelas urbanas, explorando além do limite as condições oferecidas pelo sistema de ruas e o 
suporte físico (condições de permeabilidade do solo, de recarga, estabilidade do solo).

Nesse campo de disputa, que é a cidade capitalista - ainda mais as de formação periférica -, o Sistema de Espaços Livres (SEL) fica dialeticamente condicionado pela interação entre agentes produtores do espaço urbano, legislação urbanística e morfologias existentes. A seguir, serão apresentadas observações recentes a respeito - iluminando elementos de desarticulação nas estratégias de operação dos agentes envolvidos na produção da cidade e da gestão urbanística para com a estruturação de um SEL e a forma limitada como são apropriados pela população.

\section{MORFOLOGIAS}

Neste artigo o termo morfologias é utilizado para designar o conjunto de elementos que compõe a paisagem urbana, tais como edificações, ruas, espaços livres, assim como os processos sociais que envolvem suas dinâmicas de modificações, incluindo a classificação do tecido urbano em função da concentração e dispersão da massa edificada e dos padrões socioeconômicos da ocupação (quadro 1 e mapa 2).

O Grupo de Trabalho Identificação de Morfologias em Belém considerou importante o processo de transformação que vem ocorrendo na área de expansão da cidade, marcado pela implantação de condomínios fechados, conjuntos habitacionais e ênfase no viário como forma de articulação da massa construída. Enquanto processo econômico, tal fenômeno teria interdependência com a realidade da Primeira Légua em decorrência da pressão do mercado imobiliário por terras urbanizadas onde áreas livres da periferia se tornam locais propícios para atividades de incorporação imobiliária de larga escala.

Quadro 1 Síntese do Grupo de Trabalho Identificação de Morfologias

\begin{tabular}{|c|c|c|}
\hline Morfologia & Ocorrência & Características \\
\hline Habitações Informais & $\begin{array}{l}1^{\circ} \text { Légua Patrimonial, na paisagem da } \\
\text { baixada, nos terrenos com cotas abaixo de } \\
\text { quatro metros. }\end{array}$ & $\begin{array}{l}\text { Edificações de pequeno porte com } \\
\text { pequeno ou sem recuo e acabamento } \\
\text { precário; grande incidência do uso da } \\
\text { madeira. }\end{array}$ \\
\hline $\begin{array}{l}\text { Habitações Informais } \\
\text { (com comércio) }\end{array}$ & $\begin{array}{l}\text { Eixos viários das áreas de baixada, em } \\
\text { centralidades locais, adequadas para o uso } \\
\text { misto. }\end{array}$ & Idem anterior. \\
\hline Palafitas & $\begin{array}{l}\text { Paisagem à beira-rio; orla da Baía do } \\
\text { Guajará. }\end{array}$ & $\begin{array}{l}\text { Edificações de pequeno porte construídas } \\
\text { em madeira. }\end{array}$ \\
\hline Habitações Formais & $\begin{array}{l}\text { Tecido urbano vernacular da } 1^{\mathrm{a}} \text { Légua } \\
\text { Patrimonial. }\end{array}$ & $\begin{array}{l}\text { Edificações em alvenaria com frente de até } \\
8 \text { metros. }\end{array}$ \\
\hline $\begin{array}{l}\text { Habitações Formais } \\
\text { (Icoaraci) }\end{array}$ & Distrito de Icoaraci & $\begin{array}{l}\text { Edificações em alvenaria com recuos em } \\
\text { todos os lados em grandes lotes. }\end{array}$ \\
\hline $\begin{array}{l}\text { Conjunto } \\
\text { Habitacional de } \\
\text { Iniciativa Pública }\end{array}$ & Área de expansão & $\begin{array}{l}\text { Conjuntos habitacionais construídos nas } \\
\text { décadas de } 1970 \text { e } 1980 \text { pelo BNH; há } \\
\text { tipologias verticais e horizontais. }\end{array}$ \\
\hline
\end{tabular}


Forma Urbana de Belém e seus Desdobramentos para a Formação de um Sistema de Espaços Livres Acessível à População

\begin{tabular}{l|l|l}
\hline $\begin{array}{l}\text { Loteamento } \\
\text { Horizontal Fechado }\end{array}$ & $\begin{array}{l}\text { Área de expansão, ocupação lindeira à } \\
\text { avenida Augusto Montenegro (objeto da } \\
\text { campanha publicitária Nova Belém). }\end{array}$ & $\begin{array}{l}\text { Condomínios fechados de alto padrão. } \\
\text { Casas soltas nos lotes, com sistema viário e } \\
\text { áreas verdes e de lazer. }\end{array}$ \\
\hline Tipos variados & $\begin{array}{l}\text { Morfologia de transição na área de } \\
\text { expansão, que pode ser vertical ou } \\
\text { horizontal. }\end{array}$ & $\begin{array}{l}\text { Edificações multifamiliares de pequeno e } \\
\text { médio porte; usos industrial e misto. }\end{array}$ \\
\hline Quadras Mistas & $1^{\text {a Légua Patrimonial }}$ & $\begin{array}{l}\text { Misto de edificações horizontais com até } \\
\text { dois pavimentos e lotes verticalizados } \\
\text { (com até quarenta pavimentos); quadras } \\
\text { onde casas originais estão sob pressão do } \\
\text { mercado imobiliário. }\end{array}$ \\
\hline $\begin{array}{l}\text { Quadra Condomínio } \\
\text { Vertical }\end{array}$ & Área de expansão & $\begin{array}{l}\text { Ocupação tipo "Barra da Tijuca", } \\
\text { próxima ao shopping center; grandes } \\
\text { supermercados; altamente dependentes de } \\
\text { automóvel até que seja implantado o Bus } \\
\text { Rapid Transport (BRT) da avenida Augusto } \\
\text { Montenegro. }\end{array}$ \\
\hline $\begin{array}{l}\text { Edificações de Médio } \\
\text { Porte }\end{array}$ & Orla da baía do Guajará & $\begin{array}{l}\text { Grandes galpões, em grandes lotes, } \\
\text { destinados ao uso industrial; atualmente } \\
\text { sob pressão do mercado imobiliário, que } \\
\text { deseja liberar áreas na orla. }\end{array}$ \\
\hline Área Institucional & $\begin{array}{l}\text { Entre a 1a Légua e a área de expansão, } \\
\text { avenida Perimetral (UFPA e outros). }\end{array}$ & $\begin{array}{l}\text { Áreas com poucos volumes edificados, com } \\
\text { uso institucional, muitos espaços livres/ } \\
\text { vegetação }\end{array}$ \\
\hline
\end{tabular}

Fonte: Produzido por José Julio Lima a partir das análises da base cartográfica do projeto Quapá-SEL e de imagens do Google Earth elaboradas pelos participantes do Grupo de Trabalho durante a Oficina Quapá-SEL, Belém, 2015.

A existência de praças e ruas arborizadas na Primeira Légua Patrimonial é indicador das desigualdades social e espacial da cidade, uma vez que se opõe à maior ocorrência de ocupações irregulares ou mesmo de empreendimentos privados na periferia, onde prevalece a precariedade das áreas livres. Há privatização acelerada do espaço por meio da construção de condomínios fechados e conjuntos habitacionais de altas densidades, ocasionando a saturação das áreas livres disponíveis. Por outro lado, caso se aborde o território do município de Belém, ou da Região Metropolitana, no recorte ambiental das bacias hidrográficas, serão notadas diferenças adicionais: bacias periféricas ainda relativamente próximo do centro têm permeabilidade de solo baixa, e outras, periféricas e distantes, costumam ter mais solo disponível para percolação natural. A disponibilidade espacial de locais públicos, entretanto, é favorável ao centro ou à Primeira Légua, e não à periferia ou à Segunda Légua (tabela 1 e mapa 3).

As quadras de ocupação mista no interior da Primeira Légua Patrimonial, formadas pela implantação de edifícios de apartamentos com até quarenta pavimentos e edificações horizontais remanescentes, passam por transformações em função do ritmo de aquecimento do mercado imobiliário. Há tendência a remembramentos de lotes e aumento de densidade, causando retenção de tráfego e sobrecarga de infraestrutura.

As modificações observadas em extensões específicas das orlas são destaques na análise da paisagem. Ainda que a morfologia das quadras adjacentes não tenha sido alvo de gentrificação maciça, observa-se que os parques e equipamentos nas orlas vêm atraindo modificações na paisagem. Há um primeiro indício de mudança nas ruas 
adjacentes ao Portal da Amazônia, diferente do que ocorreu nas imediações do Complexo Estação das Docas e Ver-o-Rio, onde a verticalização com gentrificação não se deu no território imediato, mas no bairro do Umarizal - inclusive devido às restrições espaciais no ambiente construído e na legislação de proteção do Centro Histórico de Belém. A imobilização de capital na forma de reserva de infraestrutura, melhorias de saneamento (construção da avenida Visconde de Souza Franco) e a implantação de supermercados e shopping centers têm se constituído em catalisadores para as transformações em curso na Primeira Légua de Belém.

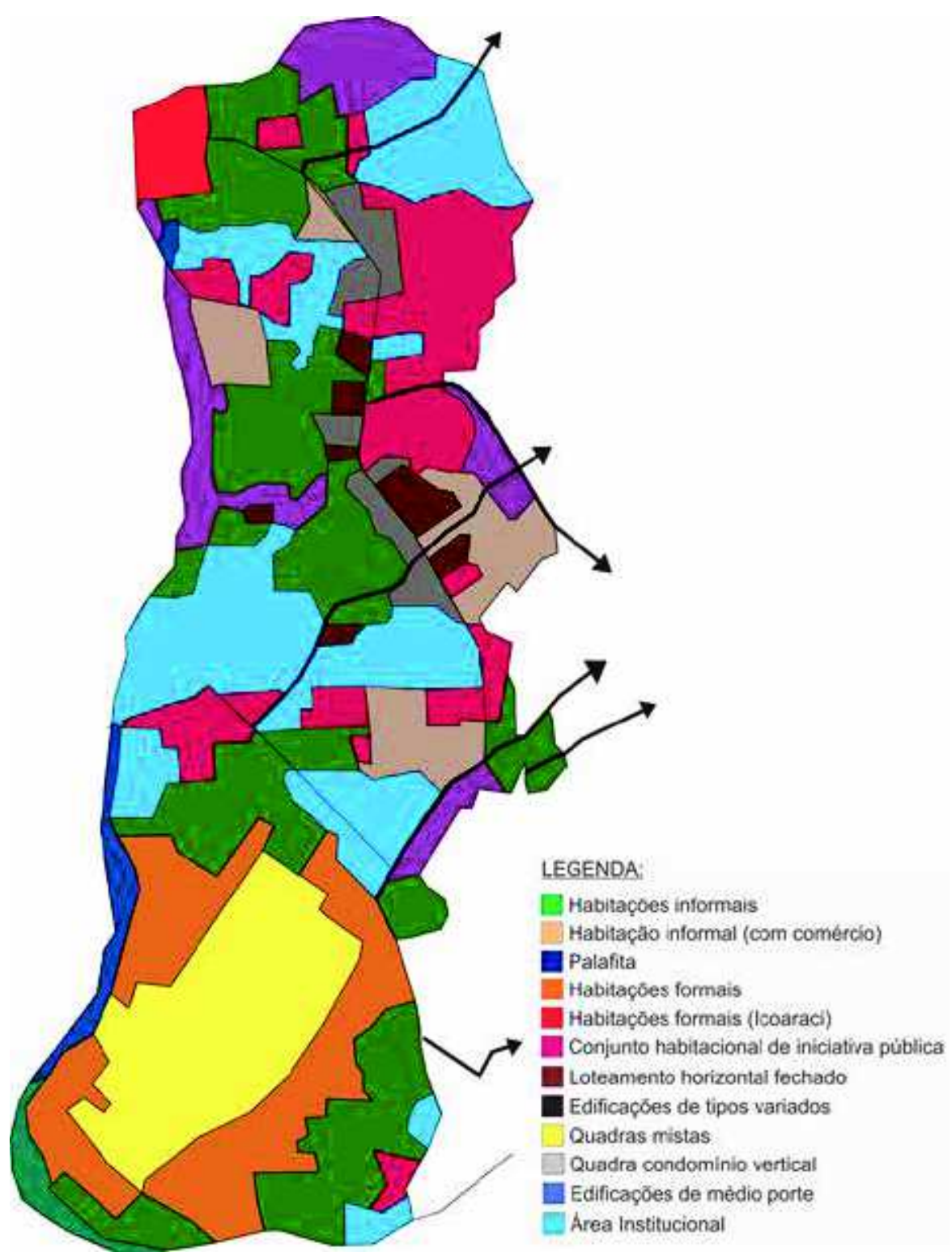

Mapa 2 Esquema síntese gerado pelo Grupo de Trabalho Identificação de Morfologias, onde é possível perceber as manchas de predominância de tipologias de ocupação na cidade de Belém.

Fonte: Mapa produzido em 2015 por Taynara Gomes sobre imagens do Google Earth 2015 e croquis elaborados pelo grupo de trabalho durante a Oficina Quapá-SEL, Belém, 2015. 
Forma Urbana de Belém e seus Desdobramentos para a Formação de um Sistema de Espaços Livres Acessível à População

Tabela 1 Declividade Média de Terreno, Taxa de Permeabilidade do Solo, População em Aglomerados Subnormais (2010) de Treze Bacias Hidrográficas que Compõem o Território mais Denso de Belém

\begin{tabular}{|c|c|c|c|c|}
\hline $\begin{array}{c}\text { Bacia } \\
\text { hidrográfica }\end{array}$ & $\begin{array}{l}\text { Declividade média } \\
\text { (mancha de } \\
\text { alagamento até a } \\
\text { periferia) } \\
\text { permeabilidade }\end{array}$ & $\begin{array}{c}\text { Taxa de } \\
\text { permeabilidade }\end{array}$ & $\begin{array}{c}\text { População em } \\
\text { Aglomerados } \\
\text { Subnormais } \\
\text { (2010) }\end{array}$ & Localização \\
\hline 1. Estrada Nova & $2.40 \%$ & $4 \%$ & 118.219 & $\begin{array}{c}\text { Primeira légua } \\
\text { patrimonial }\end{array}$ \\
\hline 2. Una & $1.80 \%$ & $5 \%$ & 187.987 & $\begin{array}{c}\text { Primeira e } \\
\text { Segunda léguas } \\
\text { patrimoniais }\end{array}$ \\
\hline 3. Tucunduba & $2.50 \%$ & $7 \%$ & 93.657 & $\begin{array}{c}\text { Primeira légua } \\
\text { patrimonial }\end{array}$ \\
\hline 4. Mata Fome & $2.90 \%$ & $27 \%$ & 38.708 & $\begin{array}{c}\text { Segunda légua } \\
\text { patrimonial }\end{array}$ \\
\hline 5. Paracuri & $2.30 \%$ & $23 \%$ & 62.221 & $\begin{array}{c}\text { Segunda légua } \\
\text { patrimonial }\end{array}$ \\
\hline 6. Pau Grande & $2.90 \%$ & $93 \%$ & 9.434 & Marituba \\
\hline 7. Macajatuba & $4.50 \%$ & $65 \%$ & 105.456 & Marituba \\
\hline 8. Maguarizinho & $3.00 \%$ & $19 \%$ & 32.610 & $\begin{array}{c}\text { Segunda légua } \\
\text { patrimonial e } \\
\text { Ananindeua }\end{array}$ \\
\hline 9. Maguari-Açu & $1.40 \%$ & $21 \%$ & 101.133 & $\begin{array}{c}\text { Segunda légua } \\
\text { patrimonial e } \\
\text { Ananindeua }\end{array}$ \\
\hline 10. Tamandaré & $4.50 \%$ & $7 \%$ & 221 & $\begin{array}{l}\text { Primeira légua } \\
\text { patrimonial }\end{array}$ \\
\hline $\begin{array}{l}\text { 11. Magalhães } \\
\text { Barata }\end{array}$ & $1.80 \%$ & $15 \%$ & - & $\begin{array}{c}\text { Primeira légua } \\
\text { patrimonial }\end{array}$ \\
\hline 12. Val-de-Cães & $0.62 \%$ & $30 \%$ & 6.057 & $\begin{array}{c}\text { Primeira e } \\
\text { Segunda léguas } \\
\text { patrimoniais }\end{array}$ \\
\hline 13. Reduto & $1.89 \%$ & $6 \%$ & - & $\begin{array}{c}\text { Primeira légua } \\
\text { patrimonial }\end{array}$ \\
\hline MÉDIA & $2.73 \%$ & $26 \%$ & 68.700 & \\
\hline
\end{tabular}

Fonte: Produzida por Juliano Ximenes e Ana Júlia Brandão, 2015. 


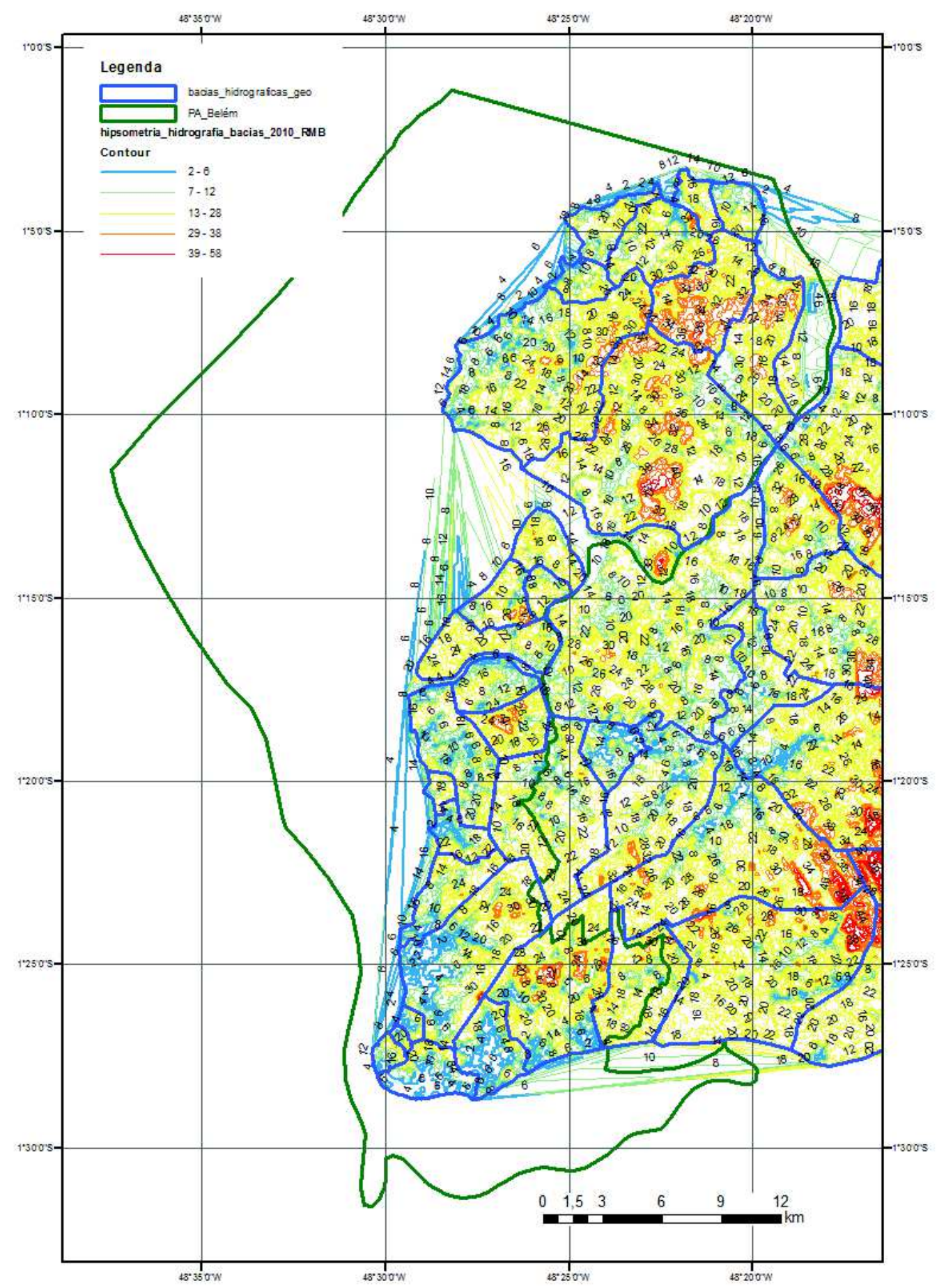

Mapa 3 Mapa hipsométrico do município de Belém mostrando o relevo predominantemente plano, com baixa altitude, e a penetração de cursos d'água.

Fonte: Idesp-PA (2009); IBGE (2010). 
Morfologias da área de expansão revelam os processos de modificação acentuados, marcados pela supressão de vegetação e manutenção de espaços verdes por meio de dispositivos legais (parque do Utinga, parque do Conjunto Médici, Área da Marinha), ao mesmo tempo em que ocorre a ampliação do sistema viário estrutural. Essa ocupação é heterogênea: apresenta assentamentos precários, conjuntos habitacionais, condomínios residenciais horizontais, áreas institucionais, estabelecimentos do baixo terciário. (DURANS, 2013).

O acesso a um SEL é dificultado pela falta de capacidade de gerenciamento da prefeitura e do governo do estado. Apesar de existirem medidas legais para a manutenção das áreas, não há ações efetivas que garantam o acesso das pessoas às áreas protegidas. $\bigcirc$ tratamento paisagístico e urbanístico de espaços livres em Belém, na periferia, é frequentemente de qualidade inferior. Espaços livres constituídos no início do século XX seguem como importantes referências de sociabilidade, e áreas ainda verdes, mais extensas, são preservadas de modo precário, sem tratamento urbanístico (não constituindo, portanto, parques urbanos) ou monitoramento e recuperação ambiental (dificultando o desempenho das chamadas funções ambientais que tais espaços poderiam ter).

\section{AGENTES PRODUTORES DO ESPAÇO URBANO}

O Grupo de Trabalho Ação dos Agentes Produtores do Espaço Urbano em Belém e a Paisagem procurou lançar hipóteses a respeito de transformações futuras sobre o tecido urbano de Belém. Foram selecionadas as principais intervenções urbanas recentes, capitaneadas por agentes que representam o estado (quadro 2), agentes cuja reprodução do próprio capital possui alguma base imobiliária (quadro 3), entre outros - cuja reprodução do capital ocorre sem prevalência de ativos imobiliários (quadro 4) - e, por último, agentes da produção do espaço dito informal.

Os agentes que representam o estado dividem-se de acordo com a esfera de atuação à qual pertencem: governo federal, governo estadual e prefeitura. Até 2016, predominam como forma de intervenção desses agentes as grandes obras de infraestrutura para melhoria da mobilidade urbana na Região Metropolitana de Belém (RMB), particularmente a construção do sistema de BRT. Nesse aspecto, nota-se que, enquanto as duas principais obras de mobilidade urbana capitaneadas pelo governo estadual (prolongamento das avenidas João Paulo II e Independência e duplicação da avenida Perimetral) possuem uma orientação que estimula o deslocamento urbano, privilegiando o automóvel, a principal intervenção urbana da prefeitura privilegia o transporte coletivo, com a construção de um sistema de BRT nas principais avenidas troncais da cidade. Inicialmente, haveria articulação entre esses tipos de transporte, contudo a expansão viária metropolitana teve o seu traçado geométrico revisto para "redução de custos", o que fez o eixo da via atravessar, no novo projeto, o Parque Ambiental do Utinga, de modo a evitar a ocupação precária, horizontal e relativamente densa de suas imediações. 
Ana Claudia Duarte Cardoso, José Julio Ferreira Lima, Raul Ventura Neto,

Roberta Menezes Rodrigues, Juliano Pamplona Ximenes, Taynara do Vale Gomes

Vale ressaltar dois projetos com alto potencial de impacto para os espaços livres da cidade, pois estão relacionados à melhoria da qualidade urbana, especialmente na área central da cidade: a construção, pela Prefeitura de Belém, da área denominada Portal da Amazônia - sobre aterro na margem do rio Guamá - e a implantação de facilidades para uso público do Parque Ambiental do Utinga pelo Governo do Estado do Pará. O primeiro projeto corresponde à urbanização de um trecho da orla fluvial da cidade com extensão executada de 1,5 quilômetros até 2015, contando com diversos equipamentos urbanos; o segundo, anunciado como projeto, objetiva a requalificação do entorno dos mananciais de água no Utinga. Em ambos os casos, haverá uma possível valorização dos terrenos em torno das novas avenidas e do parque. A intervenção do Portal da Amazônia, mesmo carente de cobertura vegetal compatível com o contexto local, aponta para uma reconfiguração substancial do perfil residencial na área e intensa mudança de usos do solo. A localização do projeto na porção mais densa da RMB tende a direcionar os eventuais benefícios do novo espaço público para a população moradora recém-chegada, de maior renda, e para visitantes, como ciclistas.

Por outro lado, apesar de o governo federal ser o principal agente financiador da maior parte dessas intervenções, por meio do Banco Nacional de Desenvolvimento Econômico e Social (BNDES), suas intervenções em Belém têm caráter diverso e menor impacto global sobre os espaços livres da cidade, como pode ser observado nas áreas dos projetos de urbanização de favelas do Programa de Aceleração do Crescimento (PAC) e na construção de conjuntos habitacionais incluídos na faixa 1 do programa Minha Casa, Minha Vida (MCMV). Ademais, é significativa a ação da ampliação da UFPA, por meio da construção de um novo campus no município de Ananindeua, em área limítrofe ao município de Belém.

Em relação aos agentes com alguma base imobiliária, a segmentação se deu pelo tipo de produto imobiliário recentemente ofertado pelo mercado: condomínios horizontais de alto padrão, condomínios clube verticais de alto padrão, condomínios verticais de médio padrão, edifícios de escritório de alto padrão, edifícios de alto padrão com vista para a baía do Guajará, condomínios do MCMV das faixas 2 e 3 e shopping centers. Como pode ser visto, há certa variedade no perfil de empreendimentos imobiliários na cidade, o que condiciona vetores de expansão e diferentes impactos sobre as características de bairro.

Em termos de impacto para os espaços livres da cidade, destacam-se os efeitos provocados pelos condomínios horizontais de alto padrão - em especial o condomínio Alphaville, construído na ilha de Outeiro a 14 quilômetros da área central da cidade, em área de vegetação densa na orla do rio Maguari - e tendência de empreendimentos dirigidos para grupos de renda média ocuparem as margens do rio Ariri, que separa os municípios de Belém e Ananindeua, destruindo Áreas de Preservação Permanente (APPs) e contrariando a legislação ambiental brasileira. Também se destacam os condomínios de médio padrão que predominam na área central da cidade e que, na maioria dos casos, foram implantados em antigos terrenos mantidos pelos proprietários fundiários locais com fins de especulação imobiliária ou em áreas livres que correspondiam ao 
Forma Urbana de Belém e seus Desdobramentos para a Formação de um Sistema de Espaços Livres Acessível à População

Quadro 2 Produtos Realizados, Características e Potencial para o SEL, Potencialidade de Transformação e Dinâmica de Produção dos Agentes Governamentais Identificados pelo Grupo de Trabalho Ação dos Agentes Produtores do Espaço Urbano em Belém e a Paisagem

\begin{tabular}{|c|c|c|c|}
\hline Agente & $\begin{array}{l}\text { Produtos } \\
\text { Realizados }\end{array}$ & $\begin{array}{l}\text { Características Ambientais e } \\
\text { Potencial para o SEL }\end{array}$ & $\begin{array}{c}\text { Potencialidade de } \\
\text { Transformação e Dinâmica de } \\
\text { Produção }\end{array}$ \\
\hline \multirow{3}{*}{$\begin{array}{l}\text { GOVERNO } \\
\text { FEDERAL }\end{array}$} & $\begin{array}{l}\text { Conjuntos habitacionais do } \\
\text { programa MCMV } 1 .\end{array}$ & $\begin{array}{l}\text { Evitar ocupação de áreas } \\
\text { ambientalmente sensíveis. }\end{array}$ & $\begin{array}{l}\text { Dinâmica de produção média } \\
\text { que incentiva loteamento no } \\
\text { entorno. }\end{array}$ \\
\hline & $\begin{array}{l}\text { Novo campus da UFPA em } \\
\text { Ananindeua. }\end{array}$ & \multirow{2}{*}{ Qualificação ambiental. } & $\begin{array}{l}\text { Criação de nova centralidade } \\
\text { e possível gentrificação do } \\
\text { entorno. }\end{array}$ \\
\hline & $\begin{array}{l}\text { Urbanização de favelas } \\
\text { (PAC 1). }\end{array}$ & & Lento. \\
\hline \multirow{6}{*}{$\begin{array}{l}\text { GOVERNO } \\
\text { ESTADUAL }\end{array}$} & $\begin{array}{l}\text { Prolongamento da av. João } \\
\text { Paulo II. }\end{array}$ & $\begin{array}{l}\text { Contorno do parque do } \\
\text { Utinga; desafogar o trânsito. }\end{array}$ & \multirow{3}{*}{$\begin{array}{l}\text { Valorização em torno da } \\
\text { rodovia e redução do trânsito } \\
\text { na via do BRT. }\end{array}$} \\
\hline & $\begin{array}{l}\text { Prolongamento da av. } \\
\text { Independência. }\end{array}$ & $\begin{array}{l}\text { Desafogar o trânsito da BR- } \\
316 .\end{array}$ & \\
\hline & Duplicação da perimetral. & $\begin{array}{l}\text { Desafogar o trânsito de } \\
\text { caminhões na área central. }\end{array}$ & \\
\hline & Terminal hidroviário. & $\begin{array}{l}\text { Alternativa de modal de } \\
\text { transporte. }\end{array}$ & $\begin{array}{l}\text { Valorização do entorno } \\
\text { imediato caso o terminal } \\
\text { tenha sucesso como modal } \\
\text { de transporte; caso contrário, } \\
\text { acentuará a segregação das } \\
\text { áreas portuárias atuais. }\end{array}$ \\
\hline & Requalificação do Utinga. & $\begin{array}{l}\text { Acessibilidade para o Parque } \\
\text { Ambiental existente em lei, mas } \\
\text { que não possui atrativos para } \\
\text { maior uso pela população. }\end{array}$ & $\begin{array}{l}\text { Pouco impacto em função da } \\
\text { existência de via periférica ao } \\
\text { parque. }\end{array}$ \\
\hline & $\begin{array}{l}\text { Nova sede da Assembleia } \\
\text { Legislativa do Pará. }\end{array}$ & $\begin{array}{l}\text { Por ser em lote nas } \\
\text { proximidades de equipamento } \\
\text { urbano gerador de } \\
\text { tráfego (Hangar Centro de } \\
\text { Convenções), aumentará o } \\
\text { trânsito. }\end{array}$ & $\begin{array}{l}\text { Valorização do entorno } \\
\text { imediato. }\end{array}$ \\
\hline \multirow{5}{*}{ PREFEITURA } & Orla Portal da Amazônia. & Qualificação ambiental. & $\begin{array}{l}\text { Valorização imobiliária e } \\
\text { gentrificação. }\end{array}$ \\
\hline & $\begin{array}{l}\text { Requalificação da av. Marquês } \\
\text { de Herval. }\end{array}$ & \multirow{2}{*}{ Qualificação ambiental da via. } & \multirow{2}{*}{$\begin{array}{l}\text { Reforço de vetor imobiliário de } \\
\text { médio e alto padrão. }\end{array}$} \\
\hline & $\begin{array}{l}\text { Requalificação da av. Duque } \\
\text { de Caxias. }\end{array}$ & & \\
\hline & $\begin{array}{l}\text { Implantação do BRT: vias, } \\
\text { faixas exclusivas, viadutos e } \\
\text { estações. }\end{array}$ & Desafogar o trânsito. & $\begin{array}{l}\text { Mudança radical nos espaços } \\
\text { das vias. }\end{array}$ \\
\hline & $\begin{array}{l}\text { Novos portos articulados ao } \\
\text { BRT. }\end{array}$ & $\begin{array}{l}\text { Alternativa de modal de } \\
\text { transporte. }\end{array}$ & $\begin{array}{l}\text { Valorização do entorno } \\
\text { imediato caso os terminais } \\
\text { tenham sucesso como modal } \\
\text { de transporte; caso contrário, } \\
\text { maior segregação das áreas } \\
\text { portuárias atuais. }\end{array}$ \\
\hline
\end{tabular}

Fonte: Elaborado por Raul Ventura Neto a partir do produto da discussão realizada durante a Oficina Quapá-SEL, Belém, 2015. 
quintal das antigas edificações, tipo de espaço livre outrora predominante na área central de Belém. Ainda sobre os impactos na área central da cidade, destacam-se os edifícios de alto padrão com vista para a baía do Guajará, que, apesar de não representarem padrão hegemônico de lançamento imobiliário, tendem a influenciar negativamente os espaços livres da cidade que possuem acesso visual à orla, na medida em que estimulam a retenção especulativa dos terrenos remanescentes pelos seus proprietários. Esse tipo de empreendimento imobiliário representa um dado relevante nas formas de apropriação da paisagem urbana em Belém.

É possível supor que, apesar dos vetores imobiliários mais dinâmicos da cidade iá terem se consolidado em alguns bairros da área central, as obras de infraestrutura urbana, capitaneadas pelo governo estadual e pela prefeitura em ruas e avenidas da cidade, tendem a contribuir para a segregação socioespacial à medida que suas faixas lindeiras são apropriadas por condomínios de alto padrão e estruturas de comércio e serviço de luxo.

Com menor grau de impacto sobre os espaços livres da área central, estão os condomínios verticais de médio padrão construídos na mais recente fronteira de expansão imobiliária na Segunda Légua patrimonial de Belém, classificada por alguns agentes do mercado como "Nova Belém". É nesse espaço da cidade que também predominam os condomínios verticais do MCMV para as faixas 2 e 3 . Nesse caso, pelo porte dos empreendimentos, normalmente capitaneados por grandes incorporadoras nacionais em atuação no circuito imobiliário local, a transformação sobre a área é intensa e acelerada. Tais empreendimentos contam com relação entre densidade populacional e área de espaços livres insuficiente, agravada pela restrição de acesso às estruturas de lazer que oferecem.

Por último, com menor impacto direto, elencaram-se os dois shopping centers de grande porte recentemente empreendidos ov em vias de finalização em Belém. Nos dois casos, constatou-se que, apesar do impacto pela transformação das áreas livres ser, em termos absolutos, inferior à maior parte da produção imobiliária voltada para o uso residencial, a capacidade desses empreendimentos de consolidarem novas centralidades urbanas é significativa. Em função disso, pode-se dizer que esse tipo de empreendimento tende a gerar efeitos indiretos sobre os espaços livres da cidade, principalmente pelo estímulo à especulação fundiária de grandes proprietários locais em áreas afetadas pela nova centralidade criada, desestimulando, por exemplo, o adensamento ao longo das principais rodovias de acesso a esses equipamentos (qQuadro 3 Produtos Realizados, Características e Potencial para os SELs, Potencialidade de Transformação e Dinâmica de Produção de Empresas de Base Imobiliária Identificados pelo Grupo Ação dos Agentes Produtores do Espaço Urbano em Belém e a Paisagem).

No que diz respeito aos agentes sem base imobiliária, os empreendimentos de maior vulto correspondem ao lançamento de hipermercados, em especial um edifício de grande porte do grupo Carrefour, previsto para ser lançado na nova orla da cidade (Portal da Amazônia) em um terreno de aproximadamente quatro hectares, que abrigava uma antiga indústria têxtil local. Nesse sentido, é possível lançar a hipótese da consolidação de uma 
Forma Urbana de Belém e seus Desdobramentos para a Formação de um Sistema de Espaços Livres Acessível à População

subcentralidade na área da Nova Orla, o que poderia atrair lançamentos imobiliários de alto e médio padrão pelo diferencial existente no valor da terra urbana no local e pela possibilidade de lançamentos imobiliários residenciais com vista para o rio Guamá.

Quadro 3 Produtos Realizados, Características e Potencial para os SELs, Potencialidade de Transformação e Dinâmica de Produção de Empresas de Base Imobiliária Identificados pelo Grupo Ação dos Agentes Produtores do Espaço Urbano em Belém e a Paisagem

\begin{tabular}{|c|c|c|}
\hline Produtos Realizados & $\begin{array}{l}\text { Características Ambientais e } \\
\text { Potencial para os SELs }\end{array}$ & $\begin{array}{c}\text { Potencialidade de } \\
\text { Transformação e Dinâmica } \\
\text { de Produção }\end{array}$ \\
\hline $\begin{array}{l}\text { Condomínio Alphaville - Alto } \\
\text { padrão }\end{array}$ & \multirow{2}{*}{$\begin{array}{l}\text { Incentivar degradação } \\
\text { ambiental. }\end{array}$} & \multirow{2}{*}{ Baixa. } \\
\hline Condomínio Miriti - Alto padrão & & \\
\hline Condomínio Club - Alto padrão & Abrindo espaços livres privados. & Sem fruição pública. \\
\hline Condomínios de Médio padrão & $\begin{array}{l}\text { Verticalização com pouco } \\
\text { espaço livre, afetando o } \\
\text { microclima e o trânsito. }\end{array}$ & Intensa. \\
\hline $\begin{array}{l}\text { Edifícios de alto padrão (com } \\
\text { escritórios) }\end{array}$ & \multirow{2}{*}{$\begin{array}{l}\text { Verticalização com bloqueio da } \\
\text { vista para a baía. }\end{array}$} & Baixa. \\
\hline $\begin{array}{l}\text { Edifícios de alto padrão (com } \\
\text { vista para baía) }\end{array}$ & & Tendência média. \\
\hline MCMV (faixa 02 e faixa 03) & $\begin{array}{l}\text { Verticalização na área de } \\
\text { expansão. }\end{array}$ & $\begin{array}{l}\text { Forte, com nova frente } \\
\text { imobiliária. }\end{array}$ \\
\hline $\begin{array}{l}\text { Parque Shopping e Bosque } \\
\text { Belém }\end{array}$ & $\begin{array}{l}\text { Consolidação de nova } \\
\text { centralidade. }\end{array}$ & $\begin{array}{l}\text { Consolidação da nova frente } \\
\text { imobiliária (Nova Belém). }\end{array}$ \\
\hline
\end{tabular}

Fonte: Elaborado por Raul Ventura Neto a partir do produto da discussão realizada durante a Oficina Quapá-SEL, Belém, 2015.

Quanto aos agentes de produção da cidade dita informal, percebe-se que, apesar de não haver ocorrido aumento considerável na migração urbano rural para o município de Belém, foi possível mensurar o aumento do número de domićlios na cidade entre os Censos de 2000 e 2010, evidenciando aumento significativo em comparação ao período de 1991 a 2000, passando de quatro mil para sete mil novos domicílios a cada ano. Ao que tudo indica, parte considerável desse crescimento corresponde a áreas da cidade que não estão incluídas no mercado formal de moradias, em que 
pese o fato de que o recorde de entrega de unidades novas de apartamentos em Belém pelos agentes do mercado imobiliário ocorre somente em 2011 e não ultrapassa 3.500 unidades. (VENTURA NETO, 2012).

Quadro 4 Produtos Realizados, Características e Potencial para os SELs, Potencialidade de Transformação e Dinâmica de Produção de Empresas sem Base Imobiliária Identificados pelo Grupo Ação dos Agentes Produtores do Espaço Urbano em Belém e a Paisagem

\begin{tabular}{l|l|l}
\hline $\begin{array}{c}\text { Produtos } \\
\text { Realizados }\end{array}$ & $\begin{array}{c}\text { Características Ambientis e } \\
\text { Potencial para os SELs }\end{array}$ & $\begin{array}{c}\text { Potencialidade de } \\
\text { Transformação e } \\
\text { Dinâmica de Produção }\end{array}$ \\
\hline $\begin{array}{l}\text { Supermercado Carrefour } \\
\text { (Augusto Montenegro) }\end{array}$ & $\begin{array}{l}\text { Ocupação de lotes na } \\
\text { rodovia Augusto Montenegro, } \\
\text { supressão vegetal e } \\
\text { impermeabilização de solo. }\end{array}$ & $\begin{array}{l}\text { Aumento de tráfego e } \\
\text { manutenção de centralidade; } \\
\text { impedimento de acesso } \\
\text { viário direto na ocupação da } \\
\text { região da rodovia Augusto } \\
\text { Montenegro; valorização do } \\
\text { solo urbano. }\end{array}$ \\
\hline
\end{tabular}

Fonte: Elaborado por Raul Ventura Neto a partir do produto da discussão realizada durante a Oficina Quapá-SEL, Belém, 2015.

\section{LEGISLAÇÃO URBANÍSTICA}

Para mensurar o impacto da legislação urbanística sobre o SEL de Belém, o Grupo de Trabalho Análise da Legislação Urbanística realizou simulações de aproveitamento de lotes a partir da legislação urbanística vigente no município, abrangendo o Plano Diretor de Belém (Lei no 8.655/2008), a Lei do Centro Histórico de Belém e seu entorno (Lei n 7.709/1994) e a Lei Complementar de Controle Urbanístico - LCCU (Lei Complementar $\left.n^{\circ} 2 / 1999\right)$, observando o Zoneamento vigente, os modelos e quadro de parâmetros de cada zona. As quadras/terrenos selecionados para simulação obedeceram aos seguintes critérios: quadras na área central de diferentes tipos; quadras livres ou com capacidade de adensamento; terrenos localizados nos vetores de verticalização: na área central e na área de expansão; terrenos grandes com capacidade de produção vertical. $\bigcirc$ quadro 5 apresenta uma síntese das simulações realizadas por zona e conforme critérios de enquadramento do lote.

O desenvolvimento de cada simulação foi discutido para verificar as possibilidades de adensamento a partir da elaboração dos cálculos dos parâmetros aplicados às áreas selecionadas. Observou-se que não existe um coeficiente básico para cada Zona, mas apenas o coeficiente mínimo e máximo - disso decorre o início da não regulamentação da cobrança do instrumento Outorga Onerosa tanto do Direito de Construir, quanto de mudança de uso do solo, caso estivesse prevista no Plano Diretor. É possível a utilização do potencial máximo sem cobrança de Outorga. Ainda assim, é considerada não computável grande quantidade de áreas, como estacionamentos, áreas de lazer, 
Forma Urbana de Belém e seus Desdobramentos para a Formação de um Sistema de Espaços Livres Acessível à População

varandas e áreas de circulação, o que faz com que o coeficiente de aproveitamento praticamente dobre em todas as zonas, sendo esse o parâmetro adotado. Deve-se notar que na elaboração do Plano Diretor do Município de Belém, aprovado em 2008,

Quadro 5 Simulações Realizadas pelo Grupo de Trabalho Análise da Legislação Urbanística para Diferentes Situações de Inserção na Cidade

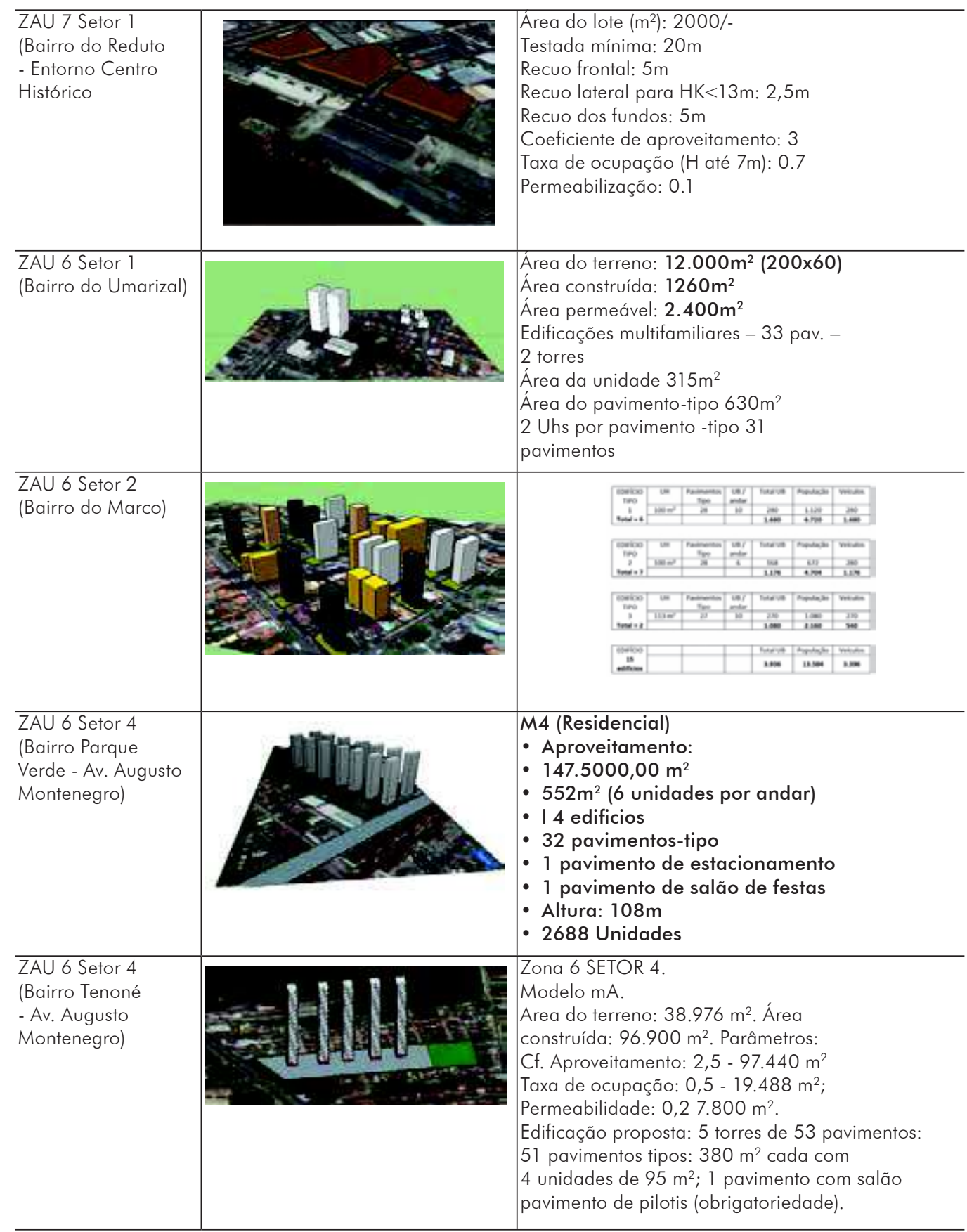

Fonte: Google Earth 2015, Belém (1999; 2008). Produzido por Taynara Gomes a partir dos resultados de grupos de trabalho da Oficina de Espaços Livres, Quapá-SEL, Belém, 2015. 
Ana Claudia Duarte Cardoso, José Julio Ferreira Lima, Raul Ventura Neto,

Roberta Menezes Rodrigues, Juliano Pamplona Ximenes, Taynara do Vale Gomes

diversas regulamentações de parâmetros urbanísticos foram deslocadas para legislações posteriores, incluindo as exigências de previsão de vagas de estacionamento em novos empreendimentos. Parâmetros existentes na LCCU n 2/1999, que regulamentavam o Plano Diretor do Município de 1993, não mais válido, substituem, de modo juridicamente irregular e distorcido, a ausência de conteúdo do atual Plano Diretor do Município.

Observou-se que o potencial construtivo é bastante alto em todas as zonas, na medida em que não há limite intermediário estabelecido. Existe grande possibilidade de verticalização em toda as zonas, com exceção na área do entorno do Centro Histórico, que possui limite de gabarito máximo. Também não há conexão entre potencial construtivo e densidade construtiva ou populacional na quadra. Poucas referências são feitas ao controle direto da densidade demográfica em áreas urbanizadas de Belém. Por outro lado, os atuais índices urbanísticos permitem que zonas outrora de caráter de preservação ambiental sejam urbanizadas no coeficiente mínimo para áreas urbanas do município - ou seja, o novo Plano Diretor cria formalmente terra urbana. Essas permissões não foram acompanhadas de implantação de nova infraestrutura para qualificar o solo e torná-lo passível de ocupação urbana adequada.

Ao longo da avenida Augusto Montenegro, onde ainda há grandes lotes vazios ou subutilizados, esses coeficientes possibilitam a produção de grandes empreendimentos verticalizados com múltiplas torres. Ainda assim, observou-se que o potencial construtivo não é todo utilizado em alguns casos, em função das exigências do mercado relacionadas a certas tipologias para o segmento econômico, como o chamado condomínio-clube. Há necessidade de destinação de área para estacionamento e lazer, limitados por questões de adequação do projeto ao perfil dos compradores, e não pela limiłação de potencial construtivo. Ainda na área da chamada "Nova Belém", regiões como o Jardim Sideral são indicadas como áreas de Operação Urbana Consorciada sem que haja sequer infraestrutura básica disponível.

A verticalização ocorre até o máximo permitido, sem que haja ponderação sobre a capacidade de suporte da infraestrutura existente, ou mesmo a cobrança de Outorga Onerosa como forma de arrecadar recursos para promover novos investimentos em infraestrutura urbana. Disso resulta prejuízo à qualidade urbanística e ambiental da cidade em praticamente toda as zonas estudadas, uma vez que a verticalização intensa tende a saturar estruturas já comprometidas pela baixa cobertura de redes de serviços e de infraestrutura urbana básica. Observou-se que as exigências quanto a áreas permeáveis também são insuficientes para garantir melhores condições ambientais para a cidade sem que haja maior distinção dos parâmetros de permeabilidade do solo nas zonas mais adensadas, ou que seja reconhecida a necessidade de manutenção de áreas permeáveis para garantia da capacidade de drenagem eficiente das ruas da cidade.

\section{CONSIDERAÇÕES FINAIS}

A diferenciação da paisagem da área central, em comparação com a área de expansão de Belém, é o principal aspecto observado neste trabalho. Apesar de a paisagem 
urbana continental ainda ter resquícios do porte das massas vegetadas próprias da região, há pouco acesso e disponibilidade deficiente e restrita. Em que pese a herança de vias arborizadas no início do século XX e de espaços de beira-rio, a ocupação urbana limita, evidentemente, as possibilidades de usufruto.

Na área central há disponibilidade de espaços públicos e áreas verdes em praças e parques, com qualidade e distribuição espacial acessível, embora ainda deficiente, tecnicamente, em relação à mancha urbana e às suas densidades demográficas. Destaca-se a concentração de espaços livres que cresce na margem dos rios (novas urbanizações). Nas áreas de ocupação informal, há grande carência de espaços livres, uma vez que os espaços públicos disponíveis tendem a ser ocupados com pequenas edificações, com lixo acumulado, mato, contribuindo para avaliações negativas sobre tais espaços, onde a proximidade da centralidade principal de Belém, para as elites, representaria um contrassenso. A área central e suas imediações deveriam, sob essa ótica socialmente desigual, ter perfil elitizado. Um dos tipos de espaços livres e do verde apreciados pela população de baixa renda são os balneários, pequenas estruturas construídas nas margens de igarapés (pequenos rios), que permitem o banho e - lazer, assim como as praias de rio. Usualmente, estão localizados fora da área mais urbanizada da Região Metropolitana, ou nas ilhas.

Existe um cinturão institucional que define o ciclo de ocupação da Primeira Légua, composto por áreas verdes majoritariamente de instituições públicas, como as Forças Armadas, instituições de ensino e pesquisa, autarquias federais. Eventualmente, a partir dos corredores de tráfego da cidade de Belém, sua visibilidade e identificação de extensão são comprometidas; tais espaços verdes preservados pelos usos institucionais não são frequentados pela população; neles não há parques implantados. Essa situação da porção continental mais densa contrasta com o entorno insular, onde o verde ainda está presente. $\mathrm{Na}$ área de expansão, predominam fragmentos de verde, que correspondem às áreas reservadas para equipamentos e praças nos conjuntos habitacionais e às áreas ainda sob o domínio do tipo de instituição listada anteriormente. Há grande potencial de aproveitamento do miolo de quadras, ainda vegetado nas de bairros como o Tapanã, com possibilidade de desmembramento de lotes e tratamento urbanístico. Costumam ser esquecidas as funções ambientais que antigos quintais e massas vegetais pulverizadas e menores têm cumprido historicamente, e o quanto sua supressão onerará novas redes de infraestrutura e comprometerá o desempenho ambiental da forma construída.

A atuação dos agentes consolida vetores imobiliários na porção mais dinâmica da cidade, com prédios de alto e médio padrão, auxiliada pelo conjunto de novas vias e alternativas de transporte público. Não se trata de novidade. A diferença é que, enquanto os vetores estavam dentro da Primeira Légua Patrimonial, a paisagem de quadras de uso misto e as centralidades de clara definição foram apoiadas pelo desenho urbano do início do século XX. Já na concentração e interação dos agentes locais, que o mercado chama de Nova Belém (área de expansão), há carência de espaços livres. O mapa 4 ajuda na visualização desse problema, facilitando a compreensão da visualização da distribuição de praças na Primeira Légua, onde há melhor infraestrutura, da localização 
Ana Claudia Duarte Cardoso, José Julio Ferreira Lima, Raul Ventura Neto,

Roberta Menezes Rodrigues, Juliano Pamplona Ximenes, Taynara do Vale Gomes

das áreas institucionais, das áreas verdes com grande potencial para apropriação (como parques) e do caráter residual das áreas verdes na área de expansão.

$\mathrm{Na}$ área de expansão, observa-se a concentração de lançamentos imobiliários em áreas previamente reservadas, envolvendo uso residencial, de comércio e serviços, que se constituem em novas centralidades, de acesso baseado no uso do automóvel em detrimento do pedestre - uma nova realidade, antes só observada no entorno de conjuntos habitacionais de grandes dimensões.

Isso deve influenciar decisivamente na sociabilidade dos novos moradores dessas áreas, isolados em condomínios, consumindo comércio e serviços também isolados, em esquemas arquitetônicos e acessos urbanísticos do tipo mall, com lazer dependente do automóvel individual, destacando a necessidade de reflexão sobre o padrão urbanístico criado na "Nova" Belém.

O confronto dos parâmetros urbanísticos do Plano Diretor com a situação em curso na cidade mostra que o potencial construtivo, em alguns casos, não é todo utilizado em função das exigências de mercado para tipologias do segmento econômico de área para estacionamento e lazer. A solução arquitetônica é determinada pela necessidade de adequação do projeto ao perfil dos compradores, e não pela restrição de potencial construtivo. Por outro lado, a possibilidade de verticalização até o limite máximo, sem ponderação sobre a capacidade de suporte da infraestrutura existente, ou mesmo a cobrança de Outorga Onerosa como forma de arrecadar recursos para promover novos investimentos em infraestrutura urbana, resultam em prejuízo para a qualidade urbanística e ambiental de Belém. Destaca-se, nessa perspectiva, que as exigências quanto a áreas permeáveis são insuficientes para garantir melhores condições ambientais sem distinção adequada entre zonas com maior densidade construtiva, ou correlação entre manutenção de permeabilidade do solo ao desempenho efetivo da drenagem urbana, conforme características da bacia hidrográfica em questão.

Há de ter especial consideração quanto à ocorrência de APPs nas margens dos rios internos e nas ilhas, principais espaços verdes do município e elementos de conexão com o bioma amazônico. O potencial paisagístico do bioma circundante (floresta tropical e de várzea), ainda é invisível para a população, ou melhor, conta com significados de invisibilidade distintos entre os diversos grupos sociais. Enquanto para uns os equipamentos da orla descortinam o rio e trazem oportunidades de convívio, para outros, são novos obstáculos para moradia e acesso democrático à cidade. 
Forma Urbana de Belém e seus Desdobramentos para a Formação de um Sistema de Espaços Livres Acessível à População
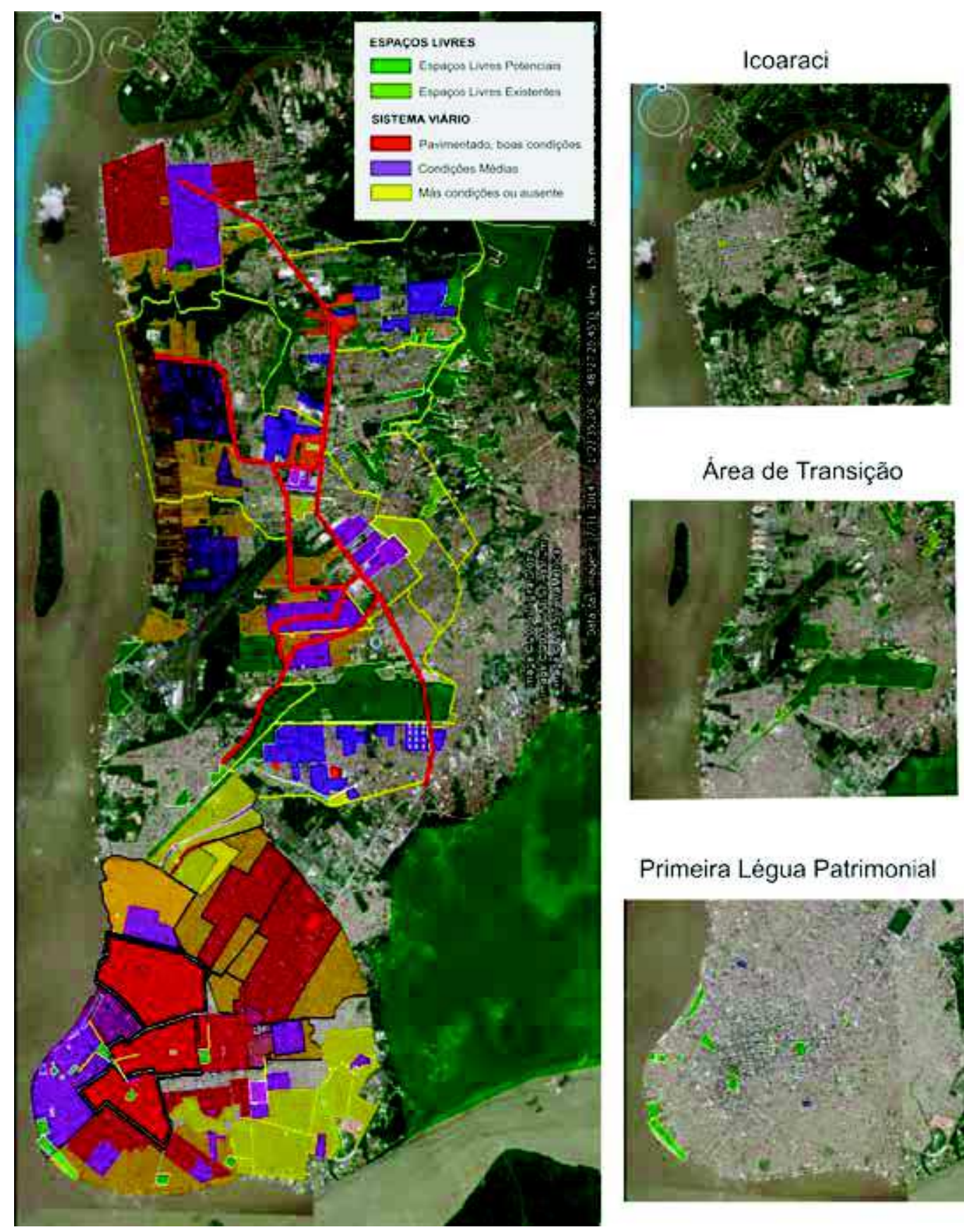

\section{Primeira Légua Patrimonial}

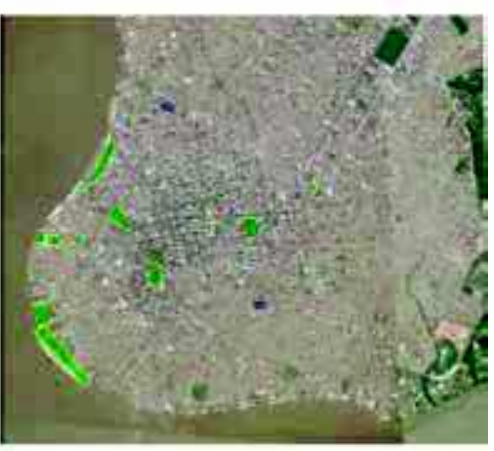

Mapa 4 Síntese da avaliação da qualidade das ruas e distribuição de espaços livres desenvolvida pelo Grupo de Trabalho Identificação de um Sistema de Espaços Livres na cidade.

Fonte: Mapa produzido em 2015 por Taynara Gomes sobre imagens do Google Earth 2015 e croquis elaborados pelo grupo de trabalho durante a oficina de espaços livres. Quapá-SEL, Belém, 2015. 
Ana Claudia Duarte Cardoso, José Julio Ferreira Lima, Raul Ventura Neto,

Roberta Menezes Rodrigues, Juliano Pamplona Ximenes, Taynara do Vale Gomes

\section{REFERÊNCIAS BIBLIOGRÁFICAS}

BELÉM. Lei n 7.709 de 18 de maio de 1994. Dispõe sobre a preservação do patrimônio histórico, artístico, cultural e paisagístico do município de Belém. Diário Oficial do Município de Belém, n 7.768, 18 mai. 1994 , $2^{\circ}$ caderno.

BELÉM. Plano Diretor do Município de Belém. Lei n 8.655, de 30 de julho de 2008. Dispõe sobre o Plano Diretor do Município de Belém, e dá outras providências. Diário Oficial do Município de Belém, 27 dez. 2013 , p. 445.

BRASIL. Lei Complementar $n^{\circ}$ 14, de 8 de junho de 1973. Estabelece as regiões metropolitanas de São Paulo, Belo Horizonte, Porto Alegre, Recife, Salvador, Curitiba, Belém e Fortaleza. Brasília: Presidência da República, 1973.

Diário Oficial da União, 11 jun. 1973, p. 5.585. Disponível em: <http://www.planalto.gov.br/ccivil_03/leis/lcp/ Lcp 1 4.htm>.

Acesso em: 11 jun. 2015.

BUENO, Laura Machado de Mello. Qualidade de vida e ambiental: avaliação e monitoramento de intervenções em assentamentos de interesse social. 81 f. Relatório de pesquisa - Pontifícia Universidade Católica de Campinas, Centro de Ciências Exatas, Ambientais e Tecnologia, Campinas, 2006. Disponível em: <http://ftp-acd.puccampinas.edu.br/pub/professores/ceatec/laurab/RELATORIO\%20PESQUISA\%2007\%20laura\%20QUALIDADE\%20 DE\%20VIDA\%20E\%20AMBIENTAL\%20AVALIAÇÃO\%20E\%20MONITORAMENTO.pdf>. Acesso em: 11 jun. 2015.

COMPANHIA DE DESENVOLVIMENTO E ADMINISTRAÇÃO DA ÁREA METROPOLITANA DE BELÉM (CODEM). Cadastro técnico multifinalitário. Belém: Prefeitura Municipal de Belém (PMB), 2003. CD-ROM.

CORRÊA, Roberto Lobato. A periodização da rede urbana da Amazônia. Revista Brasileira de Geografia, Rio de Janeiro, v. 49, n. 3, jul. 1987, p. 39-68.

CRUZ, Ernesto. História de Belém. Belém: UFPA, 1973. 2 v. (Coleção Amazônia, Série José Veríssimo).

DURANS, Renata. Tipologias de assentamento habitacional ao longo da rodovia Augusto Montenegro: estudo de caso do bairro Parque Verde, Belém (PA). 2013. 117 f. Trabalho de Conclusão de Curso (Graduação em Arquitetura e Urbanismo) - Universidade Federal do Pará, Instituto de Tecnologia, Faculdade de Arquitetura e Urbanismo, Belém, 2013.

FIX, Mariana de Azevedo Barretto. São Paulo cidade global: fundamentos financeiros de uma miragem. São Paulo: Boitempo, 2007.

IBGE (Instituto Brasileiro de Geografia e Estatística). Censo demográfico 2010. Rio de Janeiro: IBGE, 2010. Disponível em: <www.censo2010.ibge.gov.br>. Acesso em: 1 jun. 2015.

LIMA, José Júlio Ferreira. Compensatory urban form. Configuration as means of expanding social equity in Belém, Brazil. 13 f. SPACE SYNTHAX SYMPOSIUM, 3rd, 2001, Atlanta, Georgia, USA. Proceedings. Atlanta, 2001. Disponível em: <http://www.ucl.ac.uk/bartlett/3sss/papers_pdf/54 lima.pdf>. Acesso em: 28 jun. 2015.

; VENTURA NETO, R. S.; LOPES, R. S. N. Empreendimentos da 'Nova Belém’ na formação e consolidação

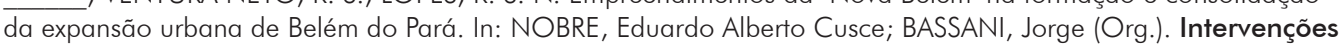
urbanas em áreas em transformação de cidades da América Latina. São Paulo: FAUUSP, 2015, v. 1, p. 163188.

MARICATO, Ermínia. Brasil, cidades: alternativas para a crise urbana. Petrópolis: Vozes, 2001.

PONTE, Juliano; BRANDÃO, Ana Júlia Domingues das Neves. Urban drainage in the Metropolitan Region of Belém, Brazil: an urbanistic study. In: SIO-LONG, Ao; ALAN HOI-SHOU, Chan; HIDEKI, Katagiri; XU, Li. (Org.). IAENG transactions on engineering sciences. Special issue for the International Association of Engineers Conferences 2014. Singapura; Londres; Hackensack: World Scientific, 2015, v. 1, p. 358-371.

TRINDADE JR., Saint-Clair. A cidade dispersa: os novos espaços de assentamentos em Belém e a reestruturação metropolitana. 1998. 366 f. Tese (Doutorado em Geografia) - Faculdade de Filosofia, Letras e Ciências Humanas, Universidade de São Paulo, São Paulo, 1998.

VENTURA NETO, Raul da Silva. Circuito imobiliário e a cidade: coalizões urbanas e dinâmicas de acumulação do capital no espaço intraurbano de Belém. 2012. 202 f. Belém. Dissertação (Mestrado em Arquitetura e Urbanismo) - Instituto de Tecnologia Arquitetura e Urbanismo da Universidade Federal do Pará, Belém, 2012.

Nota do editor

Submissão: 30 jul. 2015

Aprovação: 26 out. 2015 